\title{
Trophic ecology of sea urchins in coral-rocky reef systems, Ecuador
}

Nancy Cabanillas-Terán, Peggy Loor-Andrade, Ruber Rodríguez-Barreras, Jorge Cortés

Sea urchins are important grazers and influence reef development in the Eastern Tropical Pacific (ETP). Diadema mexicanum and Eucidaris thouarsii are the most important sea urchins on the Ecuadorian coastal reefs. This study provided a trophic scenario for these two species of echinoids in the coral-rocky reef bottoms of the Ecuadorian coast, using stable isotopes. We evaluated the relative proportion of algal resources assimilated, and trophic niche of the two sea urchins in the most southern coral-rocky reefs of the ETP in two sites with different disturbance level. Bayesian models were used to estimate the contribution of algal sources, niche breadth, and trophic overlap between the two species. The sea urchins behaved as opportunistic feeders, although they showed differential resource assimilation. Eucidaris thouarsii is the dominant species in disturbed environments; likewise, their niche amplitude was broader than that of $D$. mexicanum when conditions were not optimal. However, there was no niche overlap between the species. The Stable Isotope Analysis in R (SIAR) indicated that both sea urchins shared limiting resources in the disturbed area, mainly Dictyota spp. (contributions of up to $85 \%$ for $D$. mexicanum and up to $75 \%$ for $E$. thouarsii). The Stable Isotope Bayesian Ellipses in $R$ (SIBER) analysis results indicated less interspecific competition in the undisturbed site. Our results suggested a trophic niche partitioning between sympatric sea urchin species in coastal areas of the ETP, but the limitation of resources could lead to trophic overlap and stronger habitat degradation. 


\section{Trophic ecology of sea urchins in coral-rocky reef systems, Ecuador}

2 Nancy Cabanillas-Terán ${ }^{1 *}$, Peggy Loor-Andrade ${ }^{1}$, Ruber Rodríguez-Barreras ${ }^{2}$, Jorge Cortés $^{3}$

3

1

3

.

1. Departamento Central de Investigación, Universidad Laica Eloy Alfaro de Manabí, Ciudadela Universitaria. Vía San Mateo, Manta, Manabí, EC130802, Ecuador.

2. Department of Biology, University of Puerto Rico, Río Piedras. PO Box 23360, San Juan 00931-3360, Puerto Rico.

3. Centro de Investigación en Ciencias del Mar y Limnología (CIMAR), and Escuela de Biología, Universidad de Costa Rica, San Pedro, 11501-2060 San José, Costa Rica. *corresponding author: nanchamex@gmail.com; nancy.cabanillas@uleam.edu.ec 


\section{Abstract}

25 Sea urchins are important grazers and influence reef development in the Eastern Tropical Pacific 26 (ETP). Diadema mexicanum and Eucidaris thouarsii are the most important sea urchins on the

27 Ecuadorian coastal reefs. This study provided a trophic scenario for these two species of

28 echinoids in the coral-rocky reef bottoms of the Ecuadorian coast, using stable isotopes. We 29 evaluated the relative proportion of algal resources assimilated, and trophic niche of the two sea urchins in the most southern coral-rocky reefs of the ETP in two sites with different disturbance

31 level. Bayesian models were used to estimate the contribution of algal sources, niche breadth, 32 and trophic overlap between the two species. The sea urchins behaved as opportunistic feeders, 33 although they showed differential resource assimilation. Eucidaris thouarsii is the dominant 34 species in disturbed environments; likewise, their niche amplitude was broader than that of $D$. mexicanum when conditions were not optimal. However, there was no niche overlap between the species. The Stable Isotope Analysis in R (SIAR) indicated that both sea urchins shared limiting resources in the disturbed area, mainly Dictyota spp. (contributions of up to $85 \%$ for $D$. mexicanum and up to $75 \%$ for E. thouarsii). The Stable Isotope Bayesian Ellipses in R (SIBER) analysis results indicated less interspecific competition in the undisturbed site. Our results suggested a trophic niche partitioning between sympatric sea urchin species in coastal areas of the ETP, but the limitation of resources could lead to trophic overlap and stronger habitat degradation. 


\section{Introduction}

54 As a consequence of increasing human pressure, coastal ecosystems are facing a wide range of threats, such as resource exploitation and habitat modification (Wilkinson, 1999; Dumas et al., 2007; Costello et al., 2010; Rossi, 2013). Several studies have evaluated the development of rocky bottom disturbances by analyzing the densities of echinoids and the development stage of habitats (Phillips \& Shima, 2006; Alvarado, Cortés \& Reyes-Bonilla, 2012; Hereu et al., 2012). Some of these studies have correlated different phases of benthic substrate degradation, considering sea urchin density and their association with functional algae groups (Steneck, 1983; Steneck \& Dethier, 1994). Another approach to decipher benthic dynamics is through the trophic relationships between consumers and resources using stable isotopes (Behmer \& Joern, 2008). Stable isotope analysis (SIA) has been a powerful tool to study trophic ecology, especially for those species with foraging habits for which it is difficult to use traditional techniques, such as stomach contents. Several studies have focused on sea urchins from a stable isotope approach (e.g., Minagawa \& Wada, 1984; Tomas et al., 2006; Vanderklift, Kendrick \& Smith, 2006; Wing et al., 2008; Cabanillas-Terán, 2009; Rodríguez-Barreras et al., 2015).

Stable carbon and nitrogen isotope ratios provide time-integrated information regarding feeding relationships and energy flow through food webs (DeNiro \& Epstein, 1981; Peterson \& Fry, 1987; Vander-Zanden \& Rasmussen, 2001; Carabel et al., 2006). Stable isotopes can be used to study the trophic niche of a species due to the " $\delta$-space". This is comparable to the n-dimensional space that ecologists refer to as a niche because an animal's chemical composition is directly influenced by what it consumes, as well as the habitat in which it lives (Newsome et al., 2007; Parnell et al., 2010; Boecklen et al., 2011).

Carbon is a conservative tracer used to track energy sources in food webs, while nitrogen helps determine the trophic position (Minagawa \& Wada, 1984; Vander-Zanden \& Rasmussen, 2001; Post, 2002; Phillips, 2012; Phillips et al., 2014). Carbon $\left(\delta^{13} \mathrm{C}\right)$ and nitrogen $\left(\delta^{15} \mathrm{~N}\right)$ stable isotopes have been used in marine ecosystems to determine the food habits of species (Peterson \& Fry, 1987), nutrient migrations within food webs, the trophic position of organisms and their contribution at every level (Vander-Zanden \& Rasmussen, 1996), the origin and transformation 
82 have organisms that occupy similar trophic positions coexisting in high densities (Vanderklift, 83 Kendrick \& Smith, 2006). Moreover, SIA are useful to assess the ecosystem health (e.g., Cole et 84 al., 2004; Hamaoka et al., 2010; Karube et al., 2010). For example human influence on lake 85 ecosystems were studied by Karube et al. (2010) and those authors found that signatures of $\delta^{13} \mathrm{C}$ and $\delta^{15} \mathrm{~N}$ in macroinvertebrates of the littoral zone are indicators of anthropogenic impacts from the watershed. Inorganic nitrogen loading from the watershed was recorded in $\delta^{15} \mathrm{~N}$ of snails.

Reef degradation currently has significant consequences for morpho-functionality of marine 90 environments (Hoegh-Guldberg, 1999; Mumby, Foster \& Fahy, 2005), and the Ecuadorian reefs are no exception (Glynn \& Wellington, 1983; Glynn, 1993; Guzmán \& Cortés, 1993; Glynn, 2003). Anthropogenic stressors can have synergistic effects on reefs, such as the harmful algae blooms that are becoming increasingly important drivers of variation in the sea urchin populations, as seen in other areas (Hunter \& Price, 1992; Lapointe et al., 2005; Lapointe et al., 2010).

97 Coral-rocky reefs have rarely been studied along the Ecuadorian mainland, despite the serious 98 threat by eutrophication, fisheries and other anthropogenic impacts (Guzmán \& Cortés, 1993; 99 Cortés, 1997; Cortés, 2011). Ecuadorian coral communities are important because they represent

100 the southernmost distribution in the Eastern Tropical Pacific (ETP). Ecuador has no extensive 101 reef systems, as the majority of reefs are small rocky patches with some coral colonies. 102 Nevertheless, those areas are characterized by high biodiversity, including more than a quarter of 103 the Ecuadorian continental fishes and a great number of echinoderms, sea fans, and scleractinian corals (Glynn et al., 2001; Glynn, 2003; Rivera \& Martínez, 2011).

106 Sea urchins have the capability to modify the community structure through foraging, as several 107 authors have previously mentioned (e.g., Carpenter, 1981; Carpenter, 1986; Hay, 1984; Hay \& 108 Fenical, 1988; Sala, Boudouresque \& Harmelin-Vivien, 1998), and we need to elucidate what 
109 occurs in areas where there are more than one sea urchin species which dominate the substratum 110 and their role in controlling fleshy macroalgae. The sea urchins Diadema mexicanum (Agassiz,

111 1863) and Eucidaris thouarsii (Agassiz \& Desor, 1846) are two of the most dominant benthic 112 grazers in the ETP (Guzmán \& Cortés, 1993). These two echinoids exert a strong influence on 113 the community structure (Lawrence, 1975; Glynn, Wellington \& Birkeland, 1979; Andrew, 114 1989; Underwood, 1992). In the ETP, the sea urchin E. thouarsii could be described as a major 115 herbivore in rocky reef bottoms. Its preferential resource appeared to be benthic algal turf and 116 macroalgae, but if those were not available, it feeds on other organisms, such as the corals 117 Pavona clavus, Pocillopora spp. and Porites lobata (Glynn et al., 1979; Glynn \& Wellington, 118 1983; Reaka-Kudla, Feingold \& Glynn, 1996).

120 The ratios of $\delta^{15} \mathrm{~N}$ and $\delta^{13} \mathrm{C}$ in consumers are strongly influenced by their food resources 121 (Phillips et al., 2014) and it is necessary to identify their ecological role, not only by their 122 capacity to structure the environment, but to understand the dynamics of coexistence of the sea 123 urchin populations along the Ecuadorian coast. The relative position of $\delta^{13} \mathrm{C}$ vs. $\delta^{15} \mathrm{~N}$ echinoids 124 species can be displayed in a bi-plot and help to understand food web structure and organism 125 responses to niche shifts, diet variability and human impact (Layman et al., 2007). The aim of 126 this study was to improve the knowledge and understanding of the trophic biology of $D$. 127 mexicanum and E. thouarsii in Ecuadorian rocky reefs. We determined the stable isotopes of 128 carbon and nitrogen isotope for both sea urchin species. The complexity of the littoral zone was analyzed using stable isotopes to understand the trophic interactions of these two echinoids in areas with different degree of human impact. We assume that the more developed rocky-reef and substrate associated to coral coverage will favor habitats with complex trophic interactions (see Duffy et al., 2007; Álvarez-Filip, et al., 2009; Graham \& Nash, 2013), resulting in wider isotopic echinoids niche breadth.

\section{Material \& Methods}

135 Site descriptions: This study was conducted between May and September of 2013, at two 136 localities, Los Ahorcados (LA: 0140’42"S; 8051'58"W) and Perpetuo Socorro (PS: $0^{\circ} 55^{\prime} 40^{\prime \prime} \mathrm{S}$;

137 804'25"W), in Manabí province, Ecuador (Fig. 1). The LA site was a small group of rocky 138 islets located near Machalilla National Park. Although this area was not considered a protected 
139 area, it had a very high diversity of scleractinians and octocorals (Rivera \& Martínez, 2011). LA

140 presented a rocky bottom with clear geomorphologic differences between the leeward and

141 windward areas. The leeward area were $25 \mathrm{~m}$ depth, and the windward side was mainly build by

142 octocorals (22 species), and hexacorals, such as Pavona spp., the branching corals Pocillopora

143 spp. and solitary corals. The PS site is located in front of the Port of Manta $(1.5 \mathrm{~km})$, one of the

144 most important ports in Ecuador for large pelagic fisheries (Villón \& Beltrán, 1998a; Villón \&

145 Beltrán, 1998b; Martínez-Ortíz et al., 2007) and greatly impacted by anthropogenic activities

146 (See details in Table 1). PS rocky reef is a homogenous bottom of 7-9 $\mathrm{m}$ depth, and had a

147 substrate consisted mainly of a mixture of rock and sand with scarce scleractinian corals (Pavona

148 spp. and Pocillopora spp.) and gorgonians (mainly Leptogorgia alba).

149 In order to distinguish both sites, a coral-rocky reef category was used for this study, which was 150 developed taking into account habitat complexity and type of disturbance to establish two 151 categories, namely disturbed and undisturbed (Table 1). The distance of human impact to the 152 sites, size of the fleet and type of human disturbance were considered. The rugosity index (RI), 153 which is the ratio of a length of chain following the reef contour to the linear distance between its 154 start and end point (modified of Risk, 1972) was used. To calculate the RI, we used a three-meter 155 chain five times equitably-distributed along 15 transects $(20 \mathrm{~m})$. The average RI obtained with 156 transects was used to determine the rugosity level per site, where larger numbers indicate higher 157 complexity following Alvarez-Filip et al. (2009) and Alvarez-Filip et al. (2011). Therefore 158 values of $\mathrm{RI}<1.5$ were considered low complexity and $\mathrm{RI}>1.5$ were defined as complex.

160 Collecting and processing data: We collected algal samples for identification, to calculate 161 biomass, and to carry out SIA. Algal biomass was measured using twelve 50 x $50 \mathrm{~cm}$ quadrats 162 per site. The quadrats were located randomly within the sea urchin habitat. The substrate inside 163 each quadrat was scrapped, carefully removed, collected in bags, and frozen for later analysis. 164 Macroalgae were identified to the lowest possible taxonomic level using the available keys 165 (Abbot \& Hollenberg, 1976; Afonso-Carillo \& Sansón, 1999; Littler \& Littler, 2010). The 166 sampled invertebrate and algal species for this study are not threatened. The necessary permits 167 were obtained from the Ministry of Environment of Ecuador (014AT-DPAM-MAE). 
168 In areas where the algal cover was dominated mainly by turf species (following the morpho-

169 functional category of Guidetti, 2006), we used a sniffer with a dense mesh bag coupled to a 170 compressed air tank. In the laboratory, individuals were separated into species and gently washed

171 with distilled water and dried in an oven at $50{ }^{\circ} \mathrm{C}$ for $24 \mathrm{~h}$ to measure the dry weight.

172 We collected four individuals of D. mexicanum and six of E. thouarsii in LA and twelve 173 individuals of D. mexicanum and eight of E. thouarsii in PS at the same depth range $(8-10 \mathrm{~m})$.

174 Only individuals greater than $5.0 \mathrm{~cm}$ in test diameter were collected to avoid any effect of the 175 development stage. The samples were frozen shortly after collection and processed at the 176 laboratory. The muscles of Aristotle's lanterns were removed carefully and washed from the 177 stomach contents to estimate algal assimilation by D. mexicanum and E. thouarsii. This tissue 178 provides a time-integrated measure of assimilated sources (e.g., Michener \& Schell, 1994; Ben179 David \& Schell, 2001; Polunin et al., 2001; Phillips \& Koch, 2002; Rodríguez, 2003; Tomas et 180 al., 2006).

181 The algal and echinoids muscle samples were rinsed with filtered water, dried at $50{ }^{\circ} \mathrm{C}$ during 24 182 hours, ground to a fine powder and placed in glass vial for isotope analyses. To remove 183 carbonates from some algal species (Lobophora variegata and Polysiphonia spp.), the samples 184 were washed with diluted $\mathrm{HCl}$ at $1 \mathrm{~N}$ prior to drying to avoid disturbance in the mass 185 spectrometer reading. A subsample was taken of each alga and muscle $(\sim 1 \mathrm{mg})$ to evaluate the $186{ }^{13} \mathrm{C} /{ }^{12} \mathrm{C}$ and ${ }^{15} \mathrm{~N} /{ }^{14} \mathrm{~N}$ ratios using a Thermo Electron Delta V Advantage Mass Spectrometer. 187 Carbon and nitrogen samples were analyzed in a dual isotope mode at the Geology Department, 188 University of Florida, Gainesville, Florida.

189 The isotope samples were loaded into Eppendorf capsules and placed in a 50-position automated 190 Zero Blank sample carousel on a Carlo Erba NA1500 CNS elemental analyzer. After combustion 191 in a quartz column at $1020^{\circ} \mathrm{C}$ in an oxygen-rich atmosphere, the sample gas was transported in a 192 He carrier stream and passed through a hot reduction column $\left(650{ }^{\circ} \mathrm{C}\right)$ consisting of elemental 193 copper to remove oxygen. The effluent stream then passed through a chemical (magnesium 194 perchlorate) trap to remove water, followed by a $3 \mathrm{~m}$ Gas chromatography (GC) column at $45^{\circ} \mathrm{C}$ 195 to separate $\mathrm{N}_{2}$ from $\mathrm{CO}_{2}$. The sample gas next passed into a ConFlo II preparation system and 196 into the inlet of a mass spectrometer running in continuous flow mode, where the sample gas was 
197 measured relative to laboratory reference $\mathrm{N}_{2}$ and $\mathrm{CO}_{2}$ gases. The carbon isotopic results were 198 expressed in standard delta notation relative to Vienna Pee Dee Belemnite (VPDB). The nitrogen isotopic results were expressed in standard delta notation relative to atmospheric air. The standard deviations of $\delta^{13} \mathrm{C}$ and $\delta^{15} \mathrm{~N}$ replicate analyses were estimated; the precision values were 0.074 and 0.148 for carbon and nitrogen isotope measurements, respectively. Carbon and nitrogen samples were analyzed in a dual isotope mode. Ratios are expressed as: $\left.\delta X(\%)=\left[\left(R_{\text {sample }} / R_{\text {standard }}\right)-1\right)\right] \times 1000 ;$ where $R_{\text {sample }}={ }^{13} \mathrm{C} /{ }^{12} \mathrm{C}$ or ${ }^{15} \mathrm{~N} /{ }^{14} \mathrm{~N}$.

Data analysis: The relative contribution of algae to the diet of the sea urchins D. mexicanum and E. thouarsii was estimated with a Bayesian isotopic mixing model (SIAR, Parnell \& Jackson, 2013), which included the isotopic signatures, fractionation and variability to estimate the probability distribution of the contribution of the food source to a mixture. This procedure supplied accurate information about the contribution of algal species to the sea urchin tissues recognized the main components of the diet under different conditions (Peterson, 1999; Fry 2006; Wing et al., 2008). Lipid extractions in sea urchins was not necessary since Aristotle

212 lantern's muscle is low in lipids, on the other hand when the C:N ratios are lower than 3.5 it is 213 not recommended (Post et al., 2007) see Table S1. The isotopic discrimination factor values used 214 to run the model were $2.4 \pm 1.6 \%$ (mean $\pm \mathrm{SD}$ ) for $\delta^{15} \mathrm{~N}$, and $0.4 \pm 1.3 \%$ for $\delta^{13} \mathrm{C}$ (Fry \& Sherr, 215 1984; Minagwa \& Wada, 1984; Michener \& Schell, 1994; Moore \& Semmens, 2008). The 216 results of the mixing model showing the calculated sea urchin dietary proportions were 217 represented as box plots, indicating the $25 \%, 75 \%$, and $95 \%$ of credibility intervals (Fig 2 ).

218 The niche width and overlap for the sea urchins were estimated with Stable Isotope Bayesian 219 Ellipses in R (SIBER) (Jackson et al., 2011) from the SIAR package (Parnell \& Jackson, 2013). 220 This analysis uses metrics based on ellipses and provides the standard ellipse corrected area $221\left(\mathrm{SEA}_{\mathrm{c}}\right)$ used as the trophic niche breadth and the overlap between ellipses, where values close to 2221 represent a higher trophic overlap.

223 Prior to the statistical analysis, the homogeneity and normality of variance were tested by 224 performing a Kolmogorov-Smirnov and a Cochran's test (Zar, 2010). Statistical difference was 225 performed comparing $\delta^{15} \mathrm{~N}$ and $\delta^{13} \mathrm{C}$ values between species. In addition, the algal biomass 
226 between sites was evaluated with a one-way ANOVA, with site as a fixed factor. The statistical

227 analyses were performed using $\mathrm{R}$ with an alpha of 0.05 (R Core Team, 2014).

228

229

\section{Results}

230

The benthic communities in Ecuadorian rocky reefs ranged between habitats dominated by macroalgae and live corals (LA), and habitats dominated by turf and coral skeletons (PS). Site estimates for perturbation and complexity are outlined in Table 1. LA is a site with structural complexity and dominance of branched erect algae, while PS has low structural complexity and dominance of turf (Table 1).

235

The algae collected in LA were Asparagopsis armata, Dictyota dichotoma, Lobophora 237 variegata, Polysiphonia spp., and Sargassum spp, while in PS were D. dichotoma, L. variegata, and Polysiphonia spp. The greatest algal biomass was recorded for L. variegata at both sites, while D. dichotoma was the algae with the lowest biomass at both localities (Table 2). Overall, the biomass average values ranged from $35.8 \pm 9.73 \mathrm{~g}$ (dry weight) $\mathrm{m}^{-2}$ for PS to $143.00 \pm 20.67$

$\mathrm{g} \mathrm{m}^{-2}$ in LA. We found significant differences between both sites (ANOVA, $\mathrm{df}=1, \mathrm{~F}=3.60, \mathrm{p}<$ 0.01). The overall algal $\delta^{15} \mathrm{~N}$ fluctuated from 5.05 to $9.49 \%$ (Table 3). PS displayed the highest mean values of nitrogen with $D$. dichotoma $(7.60 \pm 0.53 \%$ ). At LA, Polysiphonia spp. exhibited the highest mean value for nitrogen $\left(7.19 \pm 1.13 \%\right.$ ). We found significant differences in $\delta^{15} \mathrm{~N}$ between sites (ANOVA, $\mathrm{df}=1, \mathrm{~F}=5.29, \mathrm{p}=0.02$ ), taking into account all the algae isotopic signatures. As for $\delta^{13} \mathrm{C}$, ratios fluctuated from -23.65 to $-6.90 \%$, with LA displaying the most negative values $\left(A\right.$. armata). There was no significant difference in $\delta^{13} \mathrm{C}$ among sites (ANOVA, $\mathrm{DF}=1, \mathrm{~F}=1.41, \mathrm{p}>0.05)$.

Values of $\delta^{15} \mathrm{~N}$ were particularly different between the two species of sea urchins (ANOVA, $\mathrm{df}=$ $1, \mathrm{~F}=20.10, \mathrm{p}<0.001)$. The isotopic value of $\delta^{15} \mathrm{~N}$ for $D$. mexicanum ranged from 11.38 to 12.99\%, whereas E. thouarsii displayed values from 12.31 to $14.15 \%$. The average values of

$253 \delta^{13} \mathrm{C}$ and $\delta^{15} \mathrm{~N}$ estimated for $D$. mexicanum in LA were $-16.67 \pm 0.04$ and $11.53 \pm 0.14 \%$, respectively, while E. thouarsii displayed $-15.46 \pm 0.16 \%$ and $12.84 \pm 0.40 \%$, respectively. In 
255 PS, the $D$. mexicanum isotopic signals were $-16.25 \pm 0.39 \%$ for $\delta^{13} \mathrm{C}$ and $12.62 \pm 0.22 \%$ for $256 \delta^{15} \mathrm{~N}$; while $E$. thouarsii displayed $-15.41 \pm 0.43 \%$ for $\delta^{13} \mathrm{C}$ and $13.54 \pm 0.47 \%$ for $\delta^{15} \mathrm{~N}$. We

257 found significant differences in $\delta^{13} \mathrm{C}$ between species (ANOVA, df 1, F= 49.31, p $<0.0001$ ), and 258 the most negative values were found at LA. The $\delta^{15} \mathrm{~N}$ showed the same patterns as those algae 259 (higher values for PS). $\delta^{15} \mathrm{~N}$ ratios of both sea urchins differed between the study sites, as LA 260 reported lower values than PS (ANOVA, df $1, \mathrm{~F}=7.59, \mathrm{p}<0.01$ ). The most notorious difference 261 was due to D. mexicanum (ANOVA, df $1, \mathrm{~F}=82.41, \mathrm{p}<0.0001$ ).

262

263 The mixing models provided evidence for the contribution of different algal resources for both 264 sites and species. The SIAR analysis showed that Sargassum spp. was the most important 265 resource for D. mexicanum in LA (up to 43\%), followed by D. dichotoma and A. armata as 266 secondary resources (up to $37 \%$ for both). Likewise, Sargassum spp. was the main algal resource 267 for E. thouarsii in the same locality (up to 44\%), followed by Polysiphonia spp. (up to 41\%) 268 (Table 4). Contrasting, at PS the main macroalgal contributor was D. dichotoma for both sea 269 urchins (Fig. 2), with up to $85 \%$ of the proportional contribution for D. mexicanum and close to $27075 \%$ for E. thouarsii. Table 5 shows data on isotopic niche breadth as measured by the corrected 271 standard ellipse area (SEAc). The main difference in the trophic niche breadth was caused by $E$. 272 thouarsii with a difference probability of 52\%; overlap between species isotopic niches was not 273 found in any case (Fig. 3), but the SEAc was higher for E. thouarsii in both sites with 0.25 in LA 274 and 0.46 in PS (Table 5).

275

276

\section{Discussion}

277 There is very little information on the ecology of the Ecuadorian coast, and no data pertaining to 278 trophic relationships among sea urchins, apart from this study. The majority of the available 279 information on Ecuador came from studies conducted on Galapagos reefs (Glynn, Wellington \& 280 Birkeland, 1979; Glynn \& Wellington, 1983; Glynn, 2003; Glynn 2004; Glynn et al., 2009). The 281 rocky reefs examined in this study were selected to establish the baseline of the trophic ecology 282 of two rocky reef areas, with different disturbance levels in the Ecuadorian mainland coast. The 283 presence of $D$. mexicanum was related to the rocky bottoms of LA, where algal presence were 284 more frequent than in the disturbed site (PS). The population density of E. thouarsii was higher 
285 at the disturbed site (N. Cabanillas-Terán, unpublished data). This study demonstrated that algal 286 abundance is not always equivalent to assimilation by the consumer. For instance, L. variegata 287 displayed the lowest dietary contribution at PS and LA for both sea urchins, although it exhibited 288 the highest average biomass at both sites. Grazing preference by D. mexicanum and E. thouarsii 289 was not related to algal biomass.

290 The isotopic results characterized different algal assemblages that were specific to each rocky 291 reef bottom (branched macroalgae for LA and turf for PS). The values of $\delta^{15} \mathrm{~N}$ in algae in this 292 study ranged from $5.05 \%$ to $9.49 \%$. This result agreed with the ranges of variation reported in 293 other studies (Owens, 1987). The values of $\delta^{13} \mathrm{C}$ fluctuated from -23.65 to $-6.90 \%$ and agreed 294 with data from Fry \& Sherr (1984), who reviewed the $\delta^{13} \mathrm{C}$ data of benthic algae, noting that 295 values ranged between -30 to $-5 \%$. The different algae species constituting the community of LA 296 showed isotopic values that were closer together, but with a broader cloud distribution in the C 297 vs N biplot of points relative to what was observed in PS. This suggests a more complex trophic 298 net and shows how primary consumers interact with their resources (McClanahan, 1988; Phillips 299 \& Gregg, 2003).

300 The isotopic ratios of $\delta^{15} \mathrm{~N}$ could be influenced by two main factors. One factor pertains to 301 changes in dissolved nitrogen, although these changes primarily affect the microscopic algal 302 communities or communities living near upwelling zones (Jennings et al., 1997; Polunin \& 303 Pinnegar, 2002). The other factor is the anthropogenic impact (Bode, Alvarez-Ossorio \& Varela, 304 2006), affecting the communities near the coastline. In this case, the community most affected by 305 urban impact was PS, located in front of Manta Port. In this port, human density is higher than $3061000 \mathrm{ind} / \mathrm{km}^{-2}$, and artisanal and industrial fishery contribute to nitrogen input, as well as the 307 hotel zone and discharges from tuna processing.

309 For algae found in both sites (D. dichotoma, L. variegata and Polysiphonia spp.), the average $310 \delta^{15} \mathrm{~N}$ were higher in PS. This agrees with other areas with high anthropogenic influence where

$311 \delta^{15} \mathrm{~N}$ values tended to be higher (Wada, Kadonaga \& Matsuo, 1975; Michener \& Schell, 1994).

312 Although both localities shared species, the isotopic values for both localities were different 
313 because each system had its own structure. The erected branched algae A. armata and Sargassum

314 spp. (not found in PS), contributed to the structural complexity founded in LA.

315

316 Variations in carbon and nitrogen ratios gave us information on trophic spectrum inherent to

317 each site and the contribution of algal species to the sea urchin tissues display information about

318 how consumers assimilate the resources when they inhabit disturbed and/or undisturbed sites.

319 Although both sea urchin species can share the same food resources, we found that their

320 ecological roles were different and there are differences between species in terms of assimilation.

321 This could explain the fact that $\delta^{15} \mathrm{~N}$ values in the tissues of E. thouarsii were higher for both

322 localities, even though both sea urchin species showed a preference for the same species $D$.

323 dichotoma. No overlap of isotope niche breadth of the echinoids was found between the two

324 species (Fig. 3), but the isotopic values between species at PS were closer, suggesting increased

325 competition due to the lack of resources. This result coincided with the mixing model because

326 the two species of sea urchins preferentially consumed similar proportions of the same species.

327 Moreover the SEAc was larger for E. thouarsii at both sites, and in LA the niche trophic distance

328 between D. mexicanum and E. thouarsii was very conspicuous, while in PS the two species of

329 sea urchins are closer (Fig. 3). A low degree of feeding specialization suggests that the sea

330 urchins adapt their foraging behavior to algae availability, being most evident for E. thouarsii,

331 that exhibits a broader trophic niche.

332 The grazing behavior of these sea urchins agreed with the findings by Glynn, Wellington \&

333 Birkeland (1979) in the Galápagos Islands, as their grazing was stronger in those areas with $30 \%$

334 or less coral cover. Previous studies highlighted that E. thouarsii limited coral growth, as this

335 echinoid interfered with the development of the reef frame and with the ability to modify the

336 habitat structure (Bak, 1994; Carpenter, 1981; Sonnenholzner, Ladah \& Lafferty, 2009). We

337 considered $D$. mexicanum to be an important grazer for the rocky bottoms ecosystems,

338 considering that changes in its population caused significant changes in the algal cover of those

339 areas.

340 Our results supported the evidence that D. mexicanum and E. thouarsii were coexistent species

341 that play a significant role as herbivores. Nevertheless, they apparently eat whatever they find,

342 and the food items are incorporated differentially between the species. Diadema mexicanum 
343 grazing effect on algal diversity and community structure is important in the process of

344 formation and maintenance of rocky reefs in Ecuador. This has also been observed in other areas

345 of the ETP where D. mexicanum has a relevant role in the recruitment of corals (Alvarado,

346 Cortés \& Reyes-Bonilla, 2012). This was also observed in Caribbean reefs with D. antillarum

347 (Macintyre, Glynn \& Hinds, 2005; Mumby et al., 2006; Idjadi, Haring \& Precht, 2010; Sandin \&

348 McNamara, 2012), and in sublittoral ecosystems of the Canary Islands with D. africanum (Alves

349 et al., 2003; Tuya et al., 2004; Hernández et al., 2005; Hernández et al., 2008; Sangil et al., 2014;

350 Cabanillas-Terán et al., 2015).

351 The standard ellipses areas values (Table 5) indicated that niche partitioning may vary depending

352 on different disturbance levels between sites; however, the diets of D. mexicanum and $E$.

353 thouarsii not only depend on the disturbance condition. For instance, Dictyota dichotoma was an

354 important component of the diet of D. mexicanum and E. thouarsii in the disturbed and

355 undisturbed sites, while Polysiphonia spp. was important in disturbed bottoms, where isotopic

356 algal signals are closer to each other. This could lead to a greater number of resource overlap at

357 PS than at LA.

358 Differential assimilation and niche partitioning are just snapshots, It is important to depict how

359 the shape of the food web varies in time and space (Layman et al., 2007 \& Schmidt et al., 2007),

360 so it is necessary to carry out more extensive spatial and temporal research. Likewise it is

361 necessary to deepen research to analyze if the narrower niche amplitude (SEAc) of $D$.

362 mexicanum and its associated presence to scleractian corals (at LA) is consistent to what is

363 happening in the Caribbean, where its presence provides suitable habitat for coral recruitment.

364 The feeding success of herbivores is associated with the competition level for resources;

365 therefore, sympatric species are exposed to a potential trophic overlap. The most pristine zone

366 (LA) exhibited smaller SEAc (considering values per species) and nitrogen values, which

367 indicate a trophic niche partitioning between the main sea urchins on the Ecuadorian coast. But,

368 the limitation of resources could lead to trophic overlap and stronger habitat degradation.

370 Acknowledgements 
371 The first author is grateful to Limber Alcivar and Jorge Figueroa for their scientific diving,

372 logistic help during fieldwork and laboratory work. Thanks to the Departamento Central de

373 Investigación-Universidad Laica Eloy Alfaro de Manabí. We want to acknowledge Norman

374 Mercado and José Luis Varela for their valuable comments.

375

376

377

\section{References}

378

379

Abbott IA, Hollenberg GJ. 1976. Marine Algae of California. Stanford: Stanford University Press.

380

Afonso-Carrillo J, Sansón M. 1999. Algas, hongos y fanerógamas marinas de las islas

381

382 Canarias. Clave analítica. Series: Materiales didácticos universitarios. Santa Cruz: Universidad de La Laguna, Secretariado de Publicaciones.

383

384

385

Alvarado JJ, Cortés J, Reyes-Bonilla H. 2012. Bioerosion impact model for the sea urchin Diadema mexicanum on three Costa Rican Pacific coral reefs. Revista de Biología Tropical 60(Supplement 2):121-132.

386

387

388

389

390

391

Alvarez-Filip L, Dulvy NK, Gill JA, Côté IM, Watkinson AR. 2009. Flattening of Caribbean coral reefs: region-wide declines in architectural complexity. Proceedings of the Royal Society of London B 276, 3019-3025. Doi:10.1098/rspb.2009.0339.

Alvarez-Filip L, Dulvy NK, Côté IM, Watkinson AR, Gill JA. 2011. Coral identity underpins architectural complexity on Caribbean reefs. Ecological Applications 21: 2223-2231. DOI: 10.1098/rspb.2009.0339

Alves FMA, Chícharo LM, Serräo E, Abreu AD. 2003. Grazing by Diadema antillarum (Philippi) upon algal communities on rocky substrates. Scientia Marina 67:307-311.

Andrew NL. 1989. Contrasting ecological implications of food limitation in sea urchins and herbivorous gastropods. Marine Ecology Progress Series 51:189-193.

Bak RPM. 1994. Sea urchin bioerosion on coral reefs: place in the carbonate budget and relevant variables. Coral Reefs 13:99-103

400 Ben-David M. Schell DM. 2001. Mixing models in analyses of diet using multiple stable

401 isotopes: a response. Oecologia 127:180-184. 
402

403

404

405

406

407

408

409

410

411

412

413

414

415

416

417

418

419

420

421

422

423

424

425

426

427

428

429

430

431

432

433

434

Bode A, Alvarez-Ossorio MT, Varela M. 2006. Phytoplankton and macrophyte contributions to littoral food webs in the Galician upwelling estimated from stable isotopes. Marine Ecology Progress Series 318:89-102.

Boecklen WJ, Yarnes CT, Cook BA, James AC. 2011. On the use of stable isotopes in trophic ecology. Annual Review in Ecology and Systematics 42:411-440.

Cabanillas-Terán N. 2009. Ecología y estatus trófico del erizo de mar Diadema antillarum (Philippi, 1845) en los fondos rocosos de las Islas Canarias (Gran Canaria, España). PhD Universidad de Las Palmas de Gran Canaria. ISBN: 978-84-693-0077-0.

Cabanillas-Terán N, Martín JA, Rodríguez-Barreras R, Luque A. 2015. Size-density strategy displayed by Diadema africanum linked with the stability of urchin-barrens in the Canary Islands. Journal of the Marine Biological Association of the United Kingdom 95:145-151.

Carabel S, Godínez-Dominguez E, Verísimo LF, Freire J. 2006. An assessment of sample processing methods for stable isotope analyses of marine food webs. Journal of Experimental Marine Biology and Ecology 336:254-261.

Carpenter RC. 1981. Grazing by Diadema antillarum (Philippi) and its effects on the benthic algal community. Journal of Marine Research 39:749-765.

Carpenter RC 1986. Partitioning herbivory and its effects on coral reef algal communities. Ecological Monographs 56:345-363.

Cole ML, Valiela I, Kroeger KD, Tomasky GL, Cebrian JC, Wigand J, McKinney RA, Grady SP, Silva MHC. 2004. Assessment of a ${ }^{15} \mathrm{~N}$ isotopic method to indicate anthropogenic eutrophication in aquatic ecosystems. Journal of Environmental Quality 33:124-132.

Cortés J. 1997. Biology and geology of coral reefs of the eastern Pacific. Coral Reefs 16 (Suppl): S39-S46.

Cortés J. 2011. Eastern Tropical Pacific coral reefs. In: Hopley D, ed. The Encyclopedia of Modern Coral Reefs: Structure, Form and Process. Berlin: Springer, 351-358.

Costello MJ, Coll M, Danovaro R, Halpin P, Ojaveer H, Miloslavich P. 2010. A census of marine biodiversity knowledge, resources, and future challenges. PloS ONE, 5: e12110. doi:10.1371/journal.pone.0012110.

DeNiro MJ, Epstein S. 1981. Influence of diet on the distribution of nitrogen isotopes in animals. Geochimica et Cosmochimica Acta 45:341-351.

Duffy JE, Cardinale BJ, France KE, McIntyre PB, Thébault E, Loreau M. 2007. The functional role of biodiversity in ecosystems: incorporating trophic complexity. Ecology Letters 10:522-538. 
435 Dumas P, Kulbicki M, Chifflet S, Fichez R, Ferraris J. 2007. Environmental factors influencing urchin spatial distributions on disturbed coral reefs (New Caledonia, South Pacific). Journal of Experimental Marine Biology and Ecology 344:88-100. freshwater ecosystems. Contribution to Marine Science 27:15-47.

Fry B. 2006. Stable Isotope Ecology. New York: Springer.

Glynn PW. 1993. Coral reef bleaching: ecological perspectives. Coral Reefs 12:1-17. American Coral Reefs. Amsterdam: Elsevier Science B.V., 450-472. communities. Ecosystems 7:358-367.

Glynn PW, Wellington GM. 1983. Corals and Coral Reefs of the Galápagos Islands.

Glynn PW, Wellington GM, Birkeland C. 1979. Coral reef growth in the Galápagos: limitation by sea urchins. Science 203:47-49 panama and Ecuador during the 1997-1998 El Niño-Southern Oscillation Event: spatial/temporal patterns and comparisons with the 1982-1983 event. Bulletin of Marine Science 69:79-109.

Glynn PW, Riegl B, Romanski AMS, Baums IB. 2009. Rapid recovery of a coral reef at Darwin Island, Galapagos Islands. Galapagos Research 66:6-13.

460 Guzmán HM, Cortés J. 1993. Los arrecifes coralinos del Pacífico Oriental Ecuatorial:

461 Revisión y perspectivas. Revista de Biología Tropical 41:535-557. Koba K, eds. Earth, Life, and Isotopes. Kyoto: Kyoto University Press, 161-181.

Hay ME. 1984. Predictable spatial escapes from herbivory: how do these affect the evolution of herbivore resistance in tropical marine communities? Oecologia 64:396-407. 
Hay ME, Fenical W. 1988. Marine plant-herbivore interactions: The ecology of chemical defense. Annual Review of Ecology and Systematic 19:111-145.

Hereu B, Garcia-Rubies A, Linares C, Navarro L, Bonaviri C, Cebrian E, Zabala, M. 2012. Impact of the Sant Esteve's storm (2008) on the algal cover in infralittoral rocky photophilic communities. Final Report. Proyecto Intramural Especial Cofinanciado CEAB-CSIC PIEC 200430E599: 123-134.

Hernández JC, Clemente S, Brito A, Falcon JM, García N, Barquin J. 2005. Estado de las poblaciones de Diadema antillarum (Echinoidea: Diadematidae) y del recubrimiento de macroalgas en las Reservas Marinas de Canarias: patrones de distribución espacial. Vieraea $33: 367-383$. aff. antillarum in controlling macroalgae assemblages throughout the Canary Island (eastern subtropical Atlantic): An spatio-temporal approach. Marine Environmental Research 66:259270 .

Hobson KA. 2008. Applying isotopic methods to tracking animal movements. Terrestrial Ecology 2:45-78.

Hoegh-Guldberg O.1999. Climate change, coral bleaching and the future of the world's coral reefs. Marine and Freshwater Research 50:839-866.

Hunter MD, Price PW. 1992. Playing chutes and ladders: heterogeneity and the relative roles of bottom-up and top-down forces in natural communities. Ecology 73:724-732. promotes scleractinian coral growth and survivorship on shallow Jamaican reefs. Marine Ecology Progress Series 403:91-100. and within communities: SIBER-Stable Isotope Bayesian Ellipses in R. Journal of Animal Ecology 80:595-602.

501 Koch PL, Phillips DL. 2002. Incorporating concentration dependence in stable isotope 502 mixing models: a reply to Robbins, Hilderbrand \& Farley (2002). Oecologia 133:14-18. 
503 Lapointe BE, Barile PJ, Littler MM, Littler DS. 2005. Macroalgal blooms on southeast

504 Florida coral reefs: II. Cross-shelf discrimination of nitrogen sources indicates widespread

505 assimilation of sewage nitrogen. Harmful Algae 4:1106-1122.

506 Lapointe BE, Langton R, Bedford BJ, Potts AC, Day O, Hu C. 2010. Land-based nutrient

507

508

509

510 enrichment of the Buccoo Reef Complex and fringing coral reefs of Tobago, West Indies. Marine Pollution Bulletin 60:334-343.

511 Lawrence JM. 1975. On the relationships between marine plants and sea urchins.

512 Oceanography and Marine Biology, An Annual Review 13:213-286.

513 Littler DS, Littler MM. 2010. Marine Plants of Pacific Panama. Smithsonian Tropical Research Institute, Smithsonian Institution. Available at http://biogeodb.stri.si.edu/pacificalgae (Updated on January 2010).

516 Macintyre IG, Glynn PW, Hinds F. 2005. Evidence of the role of Diadema antillarum in the 517 promotion of coral settlement and survivorship. Coral Reefs 24:273. Montaño C, Cedeño-Figueroa L. 2007. Abundancia estacional de tiburones desembarcados en Manta-Ecuador / Seasonal abundante of Sharks landings in Manta-Ecuador. In: MartínezOrtíz J, Galván-Magaña F, eds. Tiburones en el Ecuador: Casos de estudio. Manta: EPESPO - PMRC. 9-27.

McClanahan TR. 1988. Coexistence in a sea urchin guild and its implications to coral reef diversity and degradation. Oecologia 77:210-218.

Michener RH, Schell DM. 1994. Stable isotope ratios as tracers in marine aquatic foodwebs: In Lajtha K, Michener R, eds. Stable Isotopes in Ecology and Environmental Science. Oxford: Blackwell Scientific, 138-157.

Minagawa M, Wada E. 1984. Stepwise enrichment of ${ }^{15} \mathrm{~N}$ along food chains: further evidence and the relation between ${ }^{15} \mathrm{~N}$ and animal age. Geochimica et Cosmochimica Acta 48:1135-1140.

Moore JW, Semmens BX. 2008. Incorporating uncertainty and prior information into stable isotope mixing models. Ecology Letters 11:470-480.

Mumby PJ, Foster NL, Fahy EAG. 2005. Patch dynamics of coral reef macroalgae under chronic and acute disturbance. Coral Reefs 24:681-692.

Mumby PJ, Hedley JD, Zychaluk K, Harborne AR, Blackwell PG. 2006. Revisiting the catastrophic die-off of the urchin Diadema antillarum on Caribbean coral reefs: Fresh insights on resilience from a simulation model. Ecological Modelling 196:131-148. 
538 Newsome SD, Martinez del Rio C, Bearhop S, Phillips DL. 2007. A niche for isotopic ecology. Frontiers in Ecology and the Environment 5:429-436.

540 Owens NJP. 1987. Natural variation in ${ }^{15} \mathrm{~N}$ in the marine environment. Advances in Marine 541 Biology 24: 390-451.

542 Parnell AC, Inger R, Bearhop S, Jackson AL. 2010. Source Partitioning Using Stable

543 Isotopes: Coping with Too Much Variation. PLoS ONE 5(3):e9672. doi: 544 10.1371/journal.pone.0009672.

545 Parnell AC, Jackson AL. 2013. SIAR: stable isotope analysis in R. R package version 4.2. 546 Available at http: CRAN. R-project. org/package= siar. Peterson BJ, Howarth RW, Garrett RH. 1985. Multiple stable isotopes used to trace the flow of organic matter flow in estuarine food webs. Science 227:1361-1363. Evolution, and Systematics 18:293-320.

Peterson BJ. 1999. Stable isotopes as tracers of organic matter input and transfer in benthic food webs: a review. Acta Oecologica 20:479-487.

Phillips DL. 2012. Converting isotope values to diet composition: the use of mixing models. Journal of Mammalogy 93:342-352.

Phillips DL, Gregg JW. 2003. Source partitioning using stable isotopes: coping with too many sources. Oecologia 136:261-269.

Phillips DL, Koch PL. 2002. Incorporating concentration dependence in stable isotope mixing models. Oecologia 130:114-125.

Phillips NE, Shima JS. 2006. Differential effects of suspended sediments on larval survival and settlement of New Zealand urchins Evechinus chloroticus and abalone Haliotis iris. Marine Ecology Progress Series 314:149-158. EJ. 2014. Best practices for use of stable isotope mixing models in food web studies. Canadian Journal of Zoology 92: 823-835. doi http://dx.doi.org/10.1139/cjz-2014-0127 2001. Feeding relationships in Mediterranean bathyal assemblages elucidated by stable nitrogen and carbon isotope data. Marine Ecology Progress Series 220:13-23. 
571 Post DM. 2002. Using stable isotopes to estimate trophic position models, methods, and assumptions. Ecology 83:703-718.

573 Post DM, Layman CA, Arrington DA, Takimoto G, Quattrochi J, Montaña CG. 2007. Getting to the fat of the matter: models, methods and assumptions for dealing with lipids in stable isotope analyses. Oecologia 152:179-189. for Statistical Computing, Vienna, Austria, ISBN 3-900051-07-0. Available at http://www.Rproject.org/ 193:1-6.

Rivera F, Martínez PC. 2011. Guía fotográfica de corales y octocorales: Parque Nacional Machalilla y Reserva de Producción Faunística Marino Costera Puntilla de Santa Elena. Con contribuciones de Odalisca Breedy. Ecuador: NAZCA y Conservación Internacional. levels. Marine Ecology Progress Series 251:141-151. in the sea urchin Diadema antillarum? Regional Studies in Marine Science 2:11-18. simplification of the benthic ecosystems. Ocean and Coastal Management 84:77-85.

601

602 Sala E, Boudouresque CF, Harmelin-Vivien M. 1998. Fishing, trophic cascades and the structure of algal assemblages: evaluation of an old but untested paradigm. Oikos 82:425439.

Sandin SA, McNamara DE. 2012. Spatial dynamics of benthic competition on coral reefs. Oecologia 168:1079-1090.

Sangil C, Sansón M, Díaz-Villa T, Hernández JC, Clemente S, Afonso-Carrillo J. 2014. Spatial variability, structure and composition of crustose algal communities in Diadema africanum barrens. Helgoland Marine Research 68:451-464.

Schmidt SN, Olden JD, Solomon CT, Vander-Zanden MJ. 2007. Quantitative approaches to the analysis of stable isotope food web data. Ecology 88:2793-2802. 
604 Sonnenholzner JI, Ladah LB, Lafferty KD. 2009. Cascading effects of fishing on Galapagos

605

606

607

608

609

610

611

612

613

614

615

616

617

618

619

620

621

622

623

624

625

626

627

628

629

630

631

632

633

634

635

636

637 rocky reef communities: reanalysis using corrected data. Marine Ecology Progress Series 375:209-218.

Steneck RS. 1983. Quantifying herbivory on coral reefs: just scratching the surface and still biting off more than we can chew. In: Reaka ML, ed. The Ecology of Deep and Shallow Coral Reefs, Symposia Series for Undersea Research. (Vol. 1):103-111.

Steneck RS, Dethier MN. 1994. A functional group approach to the structure of algaldominated communities. Oikos 69:476-498.

Tomas F, Álvarez-Cascos D, Turon X, Romero J. 2006. Differential element assimilation by sea grass urchin Paracentrotus lividus in seagrass beds: implications for trophic interactions. Marine Ecology Progress Series 306:125-131.

Tuya F, Boyra A, Sanchez-Jerez P, Barbera C, Haroun RJ. 2004. Relationships between rocky-reef fish assemblages, the sea urchin Diadema antillarum and macroalgae throughout the Canarian Archipelago. Marine Ecology Progress Series 278:157-169.

Underwood AJ. 1992. Competition and marine plant-animal interactions. In: John DM, Hawkins SJ, Price JH, eds. Plant-Animal Interactions in the Marine Benthos. Oxford: Clarendon Press, 443-476.

Vander-Zanden MJ, Rasmussen JB. 1996. A trophic position model of pelagic food webs: Impact on contaminant bioaccumulation in lake trout. Ecological Monographs 66:451-477.

Vander-Zanden MJ, Rasmussen JB. 2001. Variation in $\delta^{15} \mathrm{~N}$ and $\delta^{13} \mathrm{C}$ trophic fractionation: Implications for aquatic food web studies. Limnology and Oceanography 46:2061-2066.

Vanderklift MA, Kendrick GA, Smith AJ. 2006. Differences in trophic position among sympatric sea urchin species. Estuarine, Coastal and Shelf Science 66:291-297.

Villón C, Beltrán X. 1998a. Diagnóstico de la actividad pesquera en el puerto de Manta, Provincia de Manabí. Boletín Científico y Técnico. Instituto Nacional de Pesca. GuayaquilEcuador 17:1-35.

Villón C, Beltrán X. 1998b. Diagnóstico de la actividad pesquera en el puerto de San Mateo, provincia de Manabí. Boletín Científico y Técnico. Instituto Nacional de Pesca. GuayaquilEcuador, 17:127.

Wada E, Kadonaga T, Matsuo S. $1975 .{ }^{15} \mathrm{~N}$ abundance in nitrogen of naturally occurring substances and global assessment of denitrification from isotopic viewpoint. Geochemical Journal 9:139-148.

Wilkinson C. 1999. Global and local threats to coral reef functioning and existence: review and predictions. Marine and Freshwater Research 50:867-878. 
638 Wing SR, McLeod RJ, Clark KL, Frew RD. 2008. Plasticity in the diet of two echinoderm 639 species across an ecotone: microbial recycling of forest litter and bottom-up forcing of 640 populations structure. Marine Pollution Bulletin 360:115-123.

641 Zar JH. 2010. Biostatistical Analysis (5th Edition). New Jersey: Prentice Hall. 642 
644

645

646
Figures

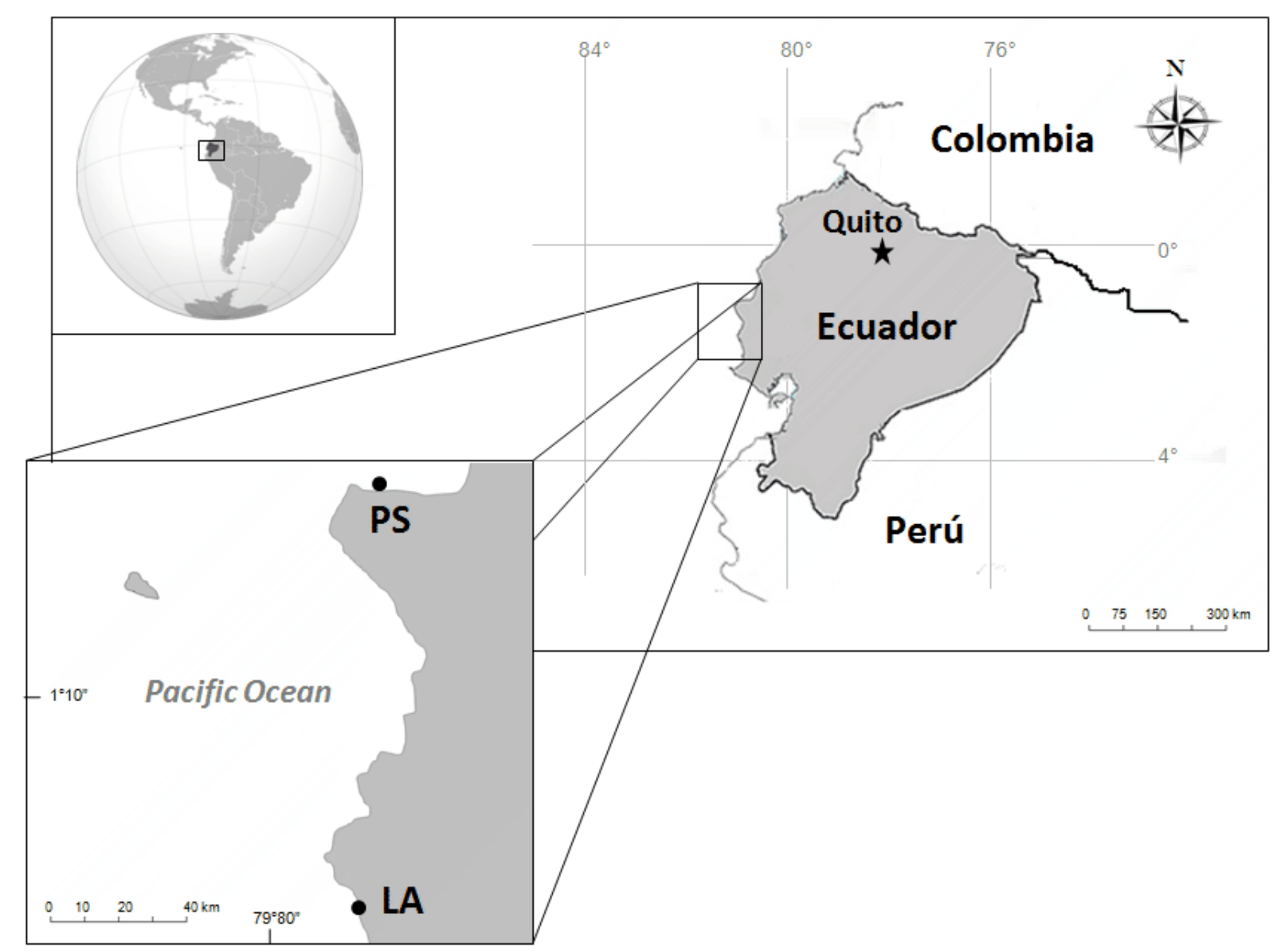

647

648 Figure 1. Study area and sampling sites in the coast of Ecuador: Los Ahorcados (LA) and 649 Perpetuo Socorro (PS). 

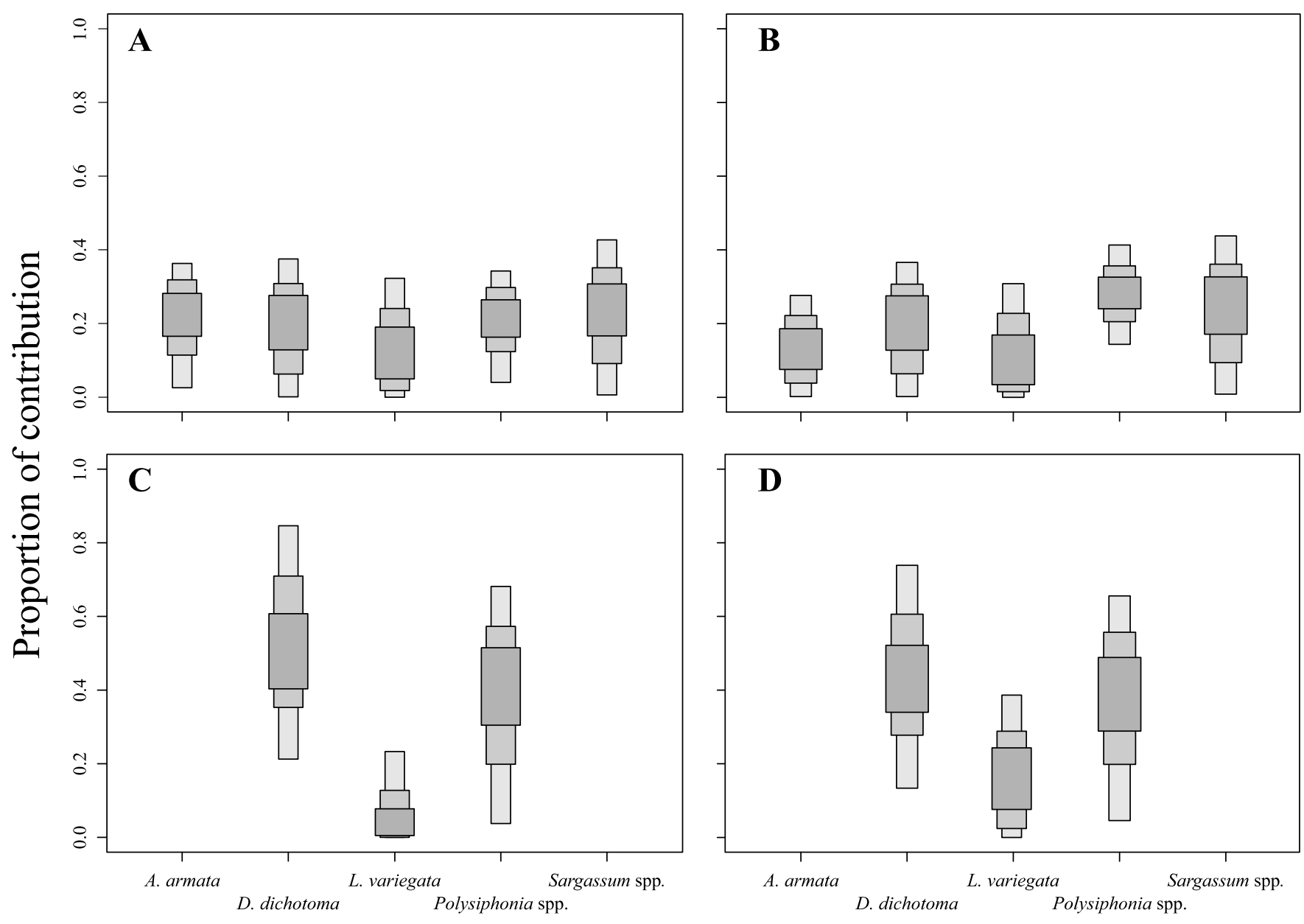

Species (algae)

651

652

653

654 655

Figure 2. Contribution rates of algae to the diet of the two sea urchin species. Results are shown as 25,75 and $95 \%$ of credibility intervals. A) Represents the contribution for Diadema mexicanum in Los Ahorcados (LA), B) for Eucidaris thouarsii in LA, C) D. mexicanum in Perpetuo Socorro (PS), and D) E. thouarsii in PS. 


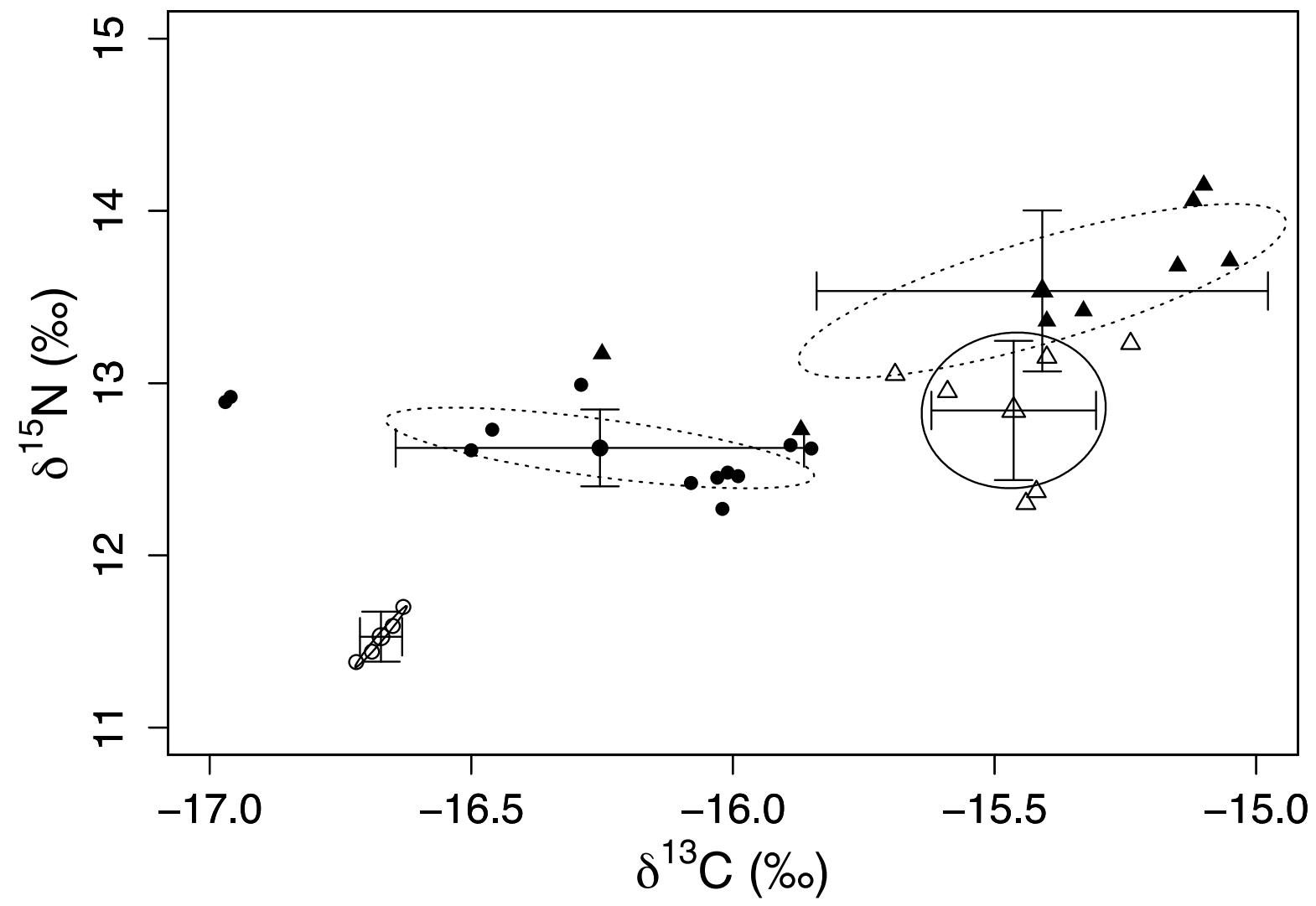

658

659

660

661
Figure 3. Isotope niche breadth of the echinoids, D. mexicanum (circles) and E. thouarsii (triangles) in Los Ahorcados (white symbols and solid line) and Perpetuo Socorro (black symbols and dotted line). 
663

664

665

666

667

Table 1. Category of coral-rocky reef sites and source of human impact.

\begin{tabular}{|c|c|c|c|c|c|}
\hline Site & $\begin{array}{c}\text { Source of } \\
\text { human impact }\end{array}$ & $\begin{array}{c}\text { Human } \\
\text { population } \\
\text { density } \\
\left(\text { ind } \cdot \mathbf{k m}^{-2} \text { ) }\right.\end{array}$ & $\begin{array}{c}\text { Distance from } \\
\text { sampling site } \\
\text { to Source of } \\
\text { human impact } \\
\text { (km) } \\
\end{array}$ & $\begin{array}{c}\text { Rugosity } \\
\text { Index (RI) }\end{array}$ & Category \\
\hline $\begin{array}{l}\text { Los Ahorcados } \\
\text { (LA) }\end{array}$ & $\begin{array}{l}\text { Artesanal Fishery } \\
+ \text { hotel zone }\end{array}$ & 54.55 & 17.24 & 2.32 & Undisturbed \\
\hline $\begin{array}{l}\text { Perpetuo } \\
\text { Socorro (PS) }\end{array}$ & $\begin{array}{l}\text { Artesanal and } \\
\text { industrial } \\
\text { Fishery+ hotel } \\
\text { zone+ industry } \\
\text { discharge }\end{array}$ & 1046.34 & 3.43 & 1.10 & Disturbed \\
\hline
\end{tabular}


672 Table 2. Average algal biomass in grams (dry weight) $\mathrm{m}^{-2} \pm$ standard deviation at Los Ahorcados 673 (LA) and Perpetuo Socorro (PS).

674

675

676

677

678

679

680

681

682

683

684

\begin{tabular}{llc}
\hline Species & \multicolumn{1}{c}{ LA } & \multicolumn{1}{c}{ PS } \\
\hline \hline A. armata & $34.32 \pm 16.98$ & - \\
D. dichotoma & $4.69 \pm 1.90$ & $0.60 \pm 0.20$ \\
L. variegata & $66.77 \pm 24.52$ & $23.26 \pm$ \\
Polysiphonia spp. & $30.73 \pm 12.82$ & $16.38 \pm 6.26$ \\
Sargassum spp. & $5.94 \pm 3.09$ & -
\end{tabular}


687 Table 3. Mean \pm standard deviation values of $\delta^{13} \mathrm{C}$ and $\delta^{15} \mathrm{~N}$ of algal genus considered in the 688 mixing model analysis taken from Los Ahorcados and Perpetuo Socorro.

\begin{tabular}{|c|c|c|c|c|c|c|c|c|c|}
\hline \multicolumn{6}{|c|}{ Los Ahorcados } & \multicolumn{4}{|c|}{ Perpetuo Socorro } \\
\hline Species & \multicolumn{2}{|c|}{$\delta^{13} \mathrm{C}$} & \multicolumn{2}{|c|}{$\delta^{15} \mathbf{N}$} & \multirow{2}{*}{$\begin{array}{c}\text { Species } \\
-\end{array}$} & \multicolumn{2}{|c|}{$\delta^{13} \mathrm{C}$} & \multicolumn{2}{|c|}{$\delta^{15} \mathbf{N}$} \\
\hline A. $\operatorname{armata}(\mathrm{n}=4)$ & -23.63 & \pm 0.10 & 5.68 & \pm 0.02 & & - & - & - & \\
\hline D. dichotomaa $(\mathrm{n}=4)$ & -17.30 & \pm 1.94 & 6.65 & \pm 0.791 & D. dichotoma $(\mathrm{n}=3)$ & -15.27 & \pm 3.05 & 7.60 & \pm 0.53 \\
\hline L. variegata $(\mathrm{n}=4)$ & -15.73 & \pm 3.331 & 5.89 & \pm 0.638 & L. variegata $(\mathrm{n}=3)$ & -12.02 & \pm 0.60 & 7.06 & \pm 1.08 \\
\hline $\begin{array}{l}\text { Polysiphonia spp. } \\
(\mathrm{n}=6)\end{array}$ & -9.33 & \pm 1.759 & 7.19 & \pm 1.129 & $\begin{array}{l}\text { Polysiphonia spp. } \\
(\mathrm{n}=4)\end{array}$ & -14.72 & \pm 3.04 & 7.38 & \pm 0.36 \\
\hline Sargassum spp. $(\mathrm{n}=4)$ & -18.30 & \pm 0.07 & 6.97 & \pm 0.06 & - & - & - & - & - \\
\hline
\end{tabular}

689 
691

692 Table 4. Average percentage (\%) contribution of algal species to the diet of the sea urchins $D$. 693 mexicanum and E. thouarsii at Los Ahorcados (LA) and Perpetuo Socorro (PS) produced by the 694 SIAR model using isotope values from algae. Minimum and maximum values for each algae are 695 shown in parentheses.

696

\begin{tabular}{llccc}
\hline \multirow{2}{*}{ Species } & \multicolumn{2}{c}{ Diadema mexicanum } & \multicolumn{2}{c}{ Eucidaris thouarsii } \\
& LA & PS & LA & PS \\
\hline \hline A. armata & $21(2-37)$ & - & $14(0-28)$ & - \\
D. dichotoma & $20(0-37)$ & $52(21-85)$ & $19(0-37)$ & $44(13-75)$ \\
L. variegata & $16(0-32)$ & $9(0-23)$ & $15(0-31)$ & $19(0-38)$ \\
Polysiphonia spp. & $20(04-35)$ & $38(3-67)$ & $28(15-41)$ & $38(4-66)$ \\
Sargassum spp. & $23(1-43)$ & - & $24(1-44)$ & -
\end{tabular}


698

699 Table 5. Trophic niche breadth of sea urchins calculated by SIBER analysis of muscle values. 700 SEAc: corrected standard ellipse area. The right column shows statistical differences in SEA.

701

\begin{tabular}{|c|c|c|}
\hline Species & SEAc & $\begin{array}{c}\text { Ellipses areas: Group differences } \\
\text { probability }(\%)\end{array}$ \\
\hline D. mexicanum (LA) & 0.005 & \\
\hline D. mexicanum (PS) & 0.218 & 1 vs $2(10.4)^{*}$ \\
\hline E. thouarsii (LA) & 0.250 & 1 vs $2(52.0)^{*}$ \\
\hline E. thouarsii (PS) & 0.457 & \\
\hline
\end{tabular}

702 